\title{
Technology development of online wallet (cashless payment) transactions in e-commerce
}

\author{
M A Jasysrurrahman ${ }^{1}$, Hadi Purnomo ${ }^{2}$ \\ \{ azmi_jays@mahasiswa.unikom.ac.id $^{1}$, $\underline{\text { hadi.purnomo@email.unikom.ac.id }}{ }^{2}$ \} \\ Departemen Sistem Informasi, Universitas Komputer Indonesia, Indonesia. ${ }^{1}$, Departmen Keuangan \\ dan Perbankan, Universitas Komputer Indonesia,Indonesia, ${ }^{2}$.
}

\begin{abstract}
The purpose of this research is to show the development of the technology of online wallet in transacting, and the benefits of using an Online Wallet. This research uses descriptive research method in which data is obtained based on the facts. The goal was to show how far the use of technology (cashless payment) as a substitute for real money in online transactions, and how excellence in technology implementation cashless if applied at the moment. The research results were obtained over human needs a versatile online and instant in the industrial age 4.0. Then some startup, as well as conventional banks, started developing technology cashless. The result is a discussion of the payment transaction system, charging the balance in doing transactions online wallet use technology.
\end{abstract}

Keywords: Online Wallet, Technology, E-Commerce, Development.

\section{Introduction}

E-Commerce and The system of the market economy raise the business competition between a company with other companies. A company finally push in order to provide the best products for their quality and affordable by the current market [1]. Presence technology cashless is the answer in order to compete with the competitor undertakes to consumer needs. The payment system that utilizes advances in the Internet to gain access to the Internet banking system. Allow consumers to buy goods bought through traders or internet access in online trade [2]. Methods of doing this online transaction form, fill out the advance balances to the online wallet, then transfer the payment for the transfer of funds from a consumer account of the recipient. Evidence has been available to make payment, including pointing to the payee and determining the amount of payment and account; debit funds from your account and to credit the account of the trust first; and identify the payee by verifying the responses received in response to one or more questions on the challenge-response is determined by the consumer. [3].

Electronic payment transactions with a safe, efficient, competitive and innovative is a very important thing and the desired element to a company. Consumers and businesses can benefit by presence technology cashless, especially in this time of transition from the former still shaped the physical trading to electronic forms [4]. E-Commerce can be a separate entity or has a function that automatically by a system that allows the transaction. After receiving the Ecommerce authorization code, the payment will be encrypted and sent to the perpetrators of online business through the network [5]. The rapid growth in the E-Commerce market is seen in the last few years around the world. With the increasing popularity of online shopping, fraud 
Debit card or credit card and personal information security is a major concern for consumers, businesses, and Banks [6]. The same thing happened in the benefits of an online wallet, one of the obstacles to successful cost-based music downloads on the internet costs high. No problem with the number, but with logistics. Credit cards offer high enough fee transactions, increasing the desire of consumers to buy is not appropriate, for example, is less than ten dollars. Perhaps more important, is their most consumers come from young people, who do not have a credit card. For people who do not have credit card, the digital sign can be used to pay for downloaded music (or other content, such as video games online) [7]. The rapid growth in the E-Commerce market is seen in the last few years around the world. The increase in online shopping portals, credit or debit card fraud and security of personal data is the engagement to merchants, banks and customers especially in terms of card [8]. Economy without cash is those who use the money mostly plastic or digital cash or money in the form of paper. The ease of conducting financial transactions is probably the greatest motivator being digital [9]. The benefits of using online payments in the world of e-commerce are expanding its market to include more and more consumers cross country [10]. The use of online payment in an online market eases the transaction process for buyers [11].

The purpose of this research is to find out whether online payment is widely used in ecommerce. Moreover, to know which e-commerce uses this online wallet. This research uses descriptive research method in which data is obtained based on the facts.

\section{Methods}

Research methods used in this study is descriptive analysis in the form of surveys. The survey method is an inquiry held to derive facts from existing symptoms and seek information in a factual world. These facts can be identified as the influence of anything after implementing an online wallet.

\section{Results And Discussion}

The development of technology encourages human progress in conducting transactions. The presence of e-commerce and some companies provide a way to pay online. The presence of these services we can refer to as an online wallet. The online wallet has a partnership with conventional banks to process a money saver set up by The Bank of Indonesia.

Performing transactions using the online wallet makes it easy to transfer our money anywhere and at any time, some of the services that we can come across as payment for online food, service tickets theaters, tickets for the plane, tickets for online sharing transportation, and the collection of funds (crowdfunding). These services can be easy, and it takes seconds. Top of the convenience offered by human habits that wallet service, as well as the top online wallet, needs to be increased (see figure 1). 


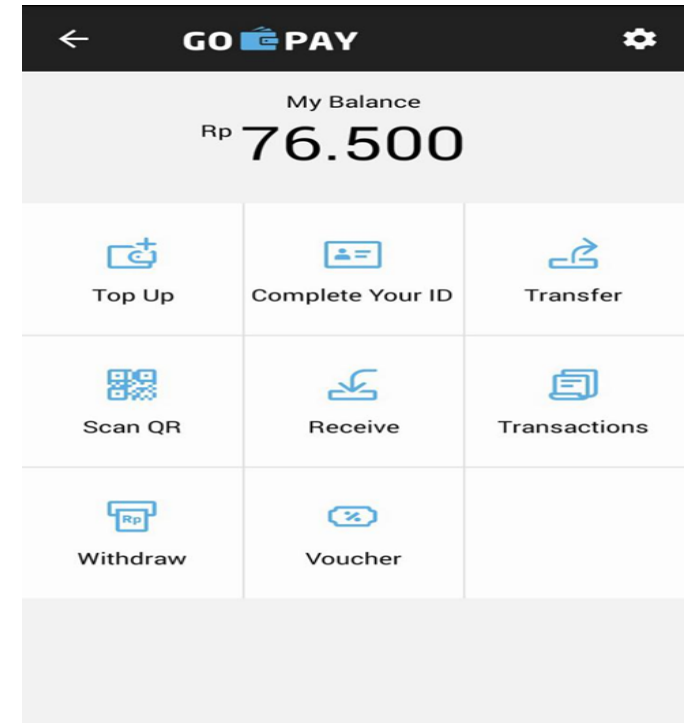

Fig 1. Top Up

Figure 1 explains the online wallet in gojek. Before making online transactions, there are options to Top Up to fill our online wallet balance. Charging balance can also be done via bank ATMS cooperating with related companies. Appropriate conditions can be accessed on the official site or application. Having already fill balance, we can pay for what we already ordered (see figure 2).

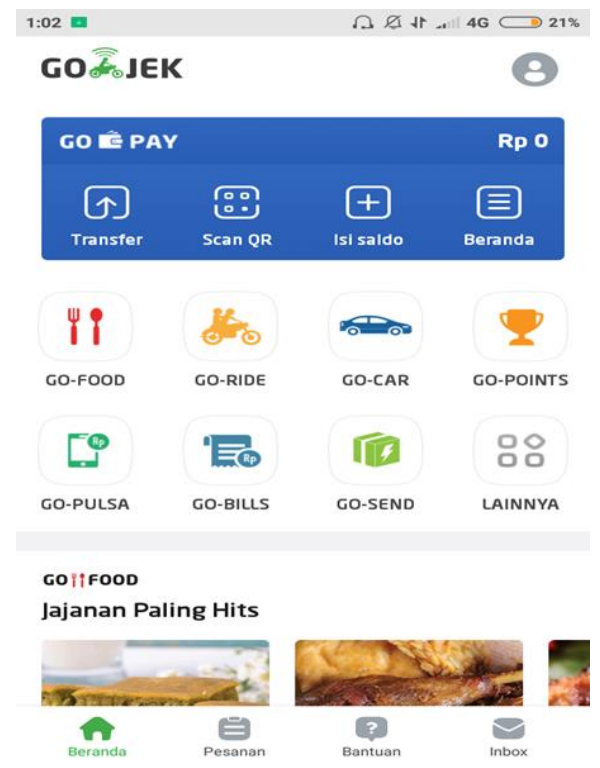

Fig 2. Main Menu

Figure 2 explains that in E-commerce there is more option. In the display of the main menu, there are several services available; the service can be easily we pay with online already filled 
wallet balance. Like paying for meals, taxi booking online, reservation gocar, and several other services that are available (see figure 3 ).

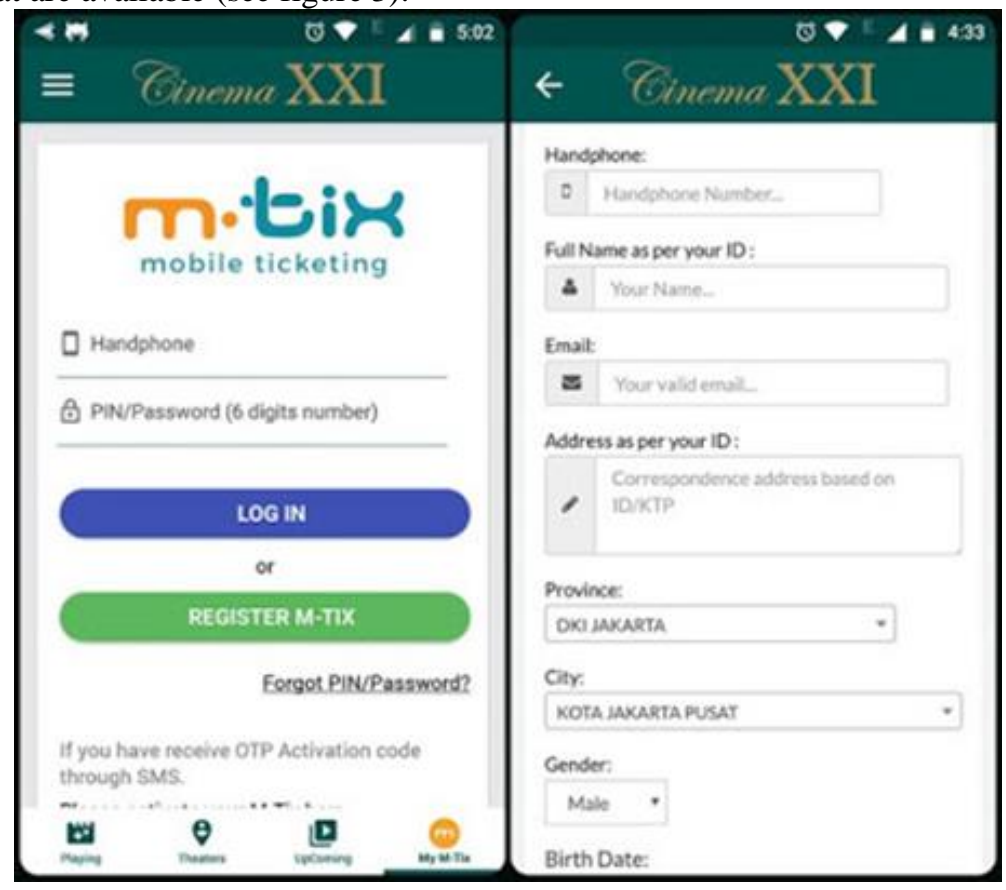

Fig 3. Payment Option

Figure 3 explains that online wallet for payment option in Mobile Tix. Purses online can we encounter in the application of M-Tix. Where we can book tickets for theaters and pay online. After the payment, we will get an email containing the replies of our transactions (see figure 4). 


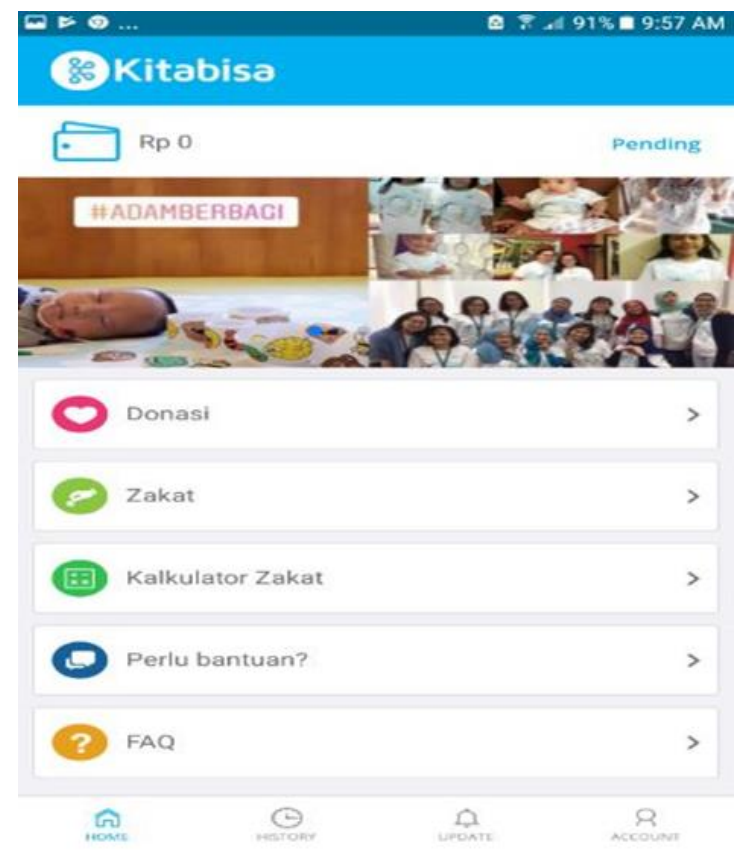

Fig 4. Payment Option

Figure 4 explains the online wallet in kitaBisa. The online wallet also plays an important role in the application of the nonprofit charity, fundraisers, donations for someone in need. Payment for a donation or charity using online already filled wallet balance. With the online wallet activities a person to donate and tithe any change (see figure 5).

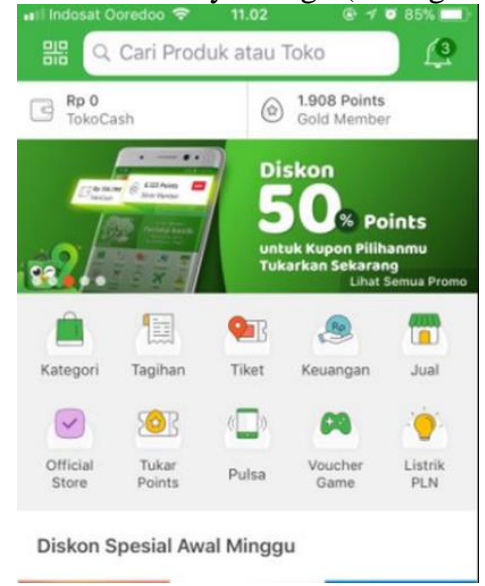

Fig 5. Main Menu

Figure 5 explains the online wallet in Tokopedia. We can use wallet Online at Tokopedia to buy goods, clothing, electronics, and to pay the bill. Wallet online makes easier for buyers and sellers in the transaction. 


\section{Conclusion}

The development of technology provides ease in performing activities, as well as in buying and selling transactions. Online transaction is the result of rapid advances in technology. Consumers can easily pay tickets for cinema, plane tickets, toll road, as well as doing a fundraiser for the awarded to the people who need it. Cashless payment transactions technology can be done anywhere, without being obstructed by the deadline and place.

\section{References}

[1] Soegoto, Eddy Soeryanto. Entrepreneurship Menjadi Pebisnis Ulung Edisi Revisi. Elex Media Komputindo, (2014).

[2] Holloway, Daniel Lee, and Albert Anderson. "Online Payment System for Merchants." U.S. Patent Application No. 11/922,346. (2016)

[3] FLEISHMAN, Jack; FUERSTENBERG, Zack. Online payment transfer and identity management system and method. U.S. Patent No 7,844,546, (2010).

[4] Naukowe Dolnośląskiej Wyższej Szkoły Przedsiębiorczości i Techniki. Studia z Nauk Technicznych, (2013).

[5] PÓLKOWSKI, ZDZISŁAW; DEACONESCU, IONUT COSMIN. Online payment systems. Zeszyty (2015)

[6] Roy, Souvik, and P. Venkateswaran. "Online payment system using steganography and visual cryptography." Electrical, Electronics and Computer Science (SCEECS), IEEE Students' Conference on. IEEE, (2014)

[7] RHOADS, Geoffrey; STAGER, Reed. Payment-based systems for internet music. U.S. Patent Application No 09/800,094, (2001)

[8] Yadav, Sangita, Priyanka Parui, and Murlidhar Dhanawade. "Secure Online Payment System Using Steganography and Visual Cryptography." (2018)

[9] Kumari, Neetu, and Jhanvi Khanna. "Cashless Payment: A Behaviourial Change To Economic Growth." Qualitative and Quantitative Research Review 2.2 (2017)

[10] Irmawati, Dewi. "Pemanfaatan e-commerce dalam dunia bisnis." Jurnal Ilmiah Orasi Bisnis-ISSN 2085 (2011).

[11] Soegoto, E. S., \& Akbar, R; August. Effect of the internet in improving business transactions with online market methods. In IOP Conference Series: Materials Science and Engineering(Vol. 407, No. 1, p. 012051). 